\title{
Hubungan Antara Usia, Kepribadian Big Five dan Mitos Hukuman Fisik Pada Remaja
}

\author{
Nafisah Siti Lasmi, Efriyani Djuwita
}

\author{
Fakultas Psikologi, Universitas Indonesia; \\ email: nafisah.siti@ui.ac.id,
}

Artikel INFO

Diterima:13 November 2020 Direvisi : 10 Februari 2021 Disetujui: 04 Maret 2021

DOI:

http://dx.doi.org/10.24014 jp.v14i2.11379
Abstrak

Saat ini penelitian mengenai mitos hukuman fisik di Indonesia masih jarang dilakukan, sedangkan hal ini perlu menjadi perhatian untuk mengetahui bagaimana penggunaan hukuman fisik pada anak masih bertahan di Indonesia. Umumnya praktik hukuman fisik di Indonesia, dapat menumbuhkan keyakinan pada remaja bahwa hukuman fisik merupakan suatu hal yang tidak membahayakan dan efektif sebagai strategi disiplin. Penelitian ini bertujuan untuk mengetahui hubungan antara usia, kepribadian Big Five dengan penerimaan mitos hukuman fisik pada remaja. Partisipan penelitian ini sebanyak 115 orang remaja berusia 13-17 tahun, berdomisili di Provinsi Jawa Barat dan termasuk dalam keluarga dengan status ekonomi menengah ke bawah. Kepribadian Big Five diukur menggunakan IPIP-BFM-25 (The International Personality Item Pool - Big Five Markers), dan penerimaan mitos hukuman fisik diukur menggunakan CPMS (Corporal Punishment Myth Scale). Uji korelasi dengan Rank Spearman menemukan bahwa terdapat hubungan yang signifikan antara usia, dimensi kepribadian agreeableness dan dimensi kepribadian conscientiousness dengan penerimaan mitos hukuman fisik. Selain itu, penelitian ini juga menemukan bahwa penerimaan mitos hukuman fisik berhubungan secara signifikan dengan intensi penggunaan hukuman fisik di masa depan. Hasil temuan ini dapat dijadikan pertimbangan dalam membuat rancangan terkait pencegahan bagi remaja dalam menggunakan hukuman fisik sebagai strategi disiplin di masa depan.

Kata-kata kunci: hukuman fisik; mitos; kepribadian Big Five; usia; remaja

\section{Relationship Between Age, Big Five Personality and Corporal Punishment Myth in Adolescents}

\begin{abstract}
Currently, research about corporal punishment myth in Indonesia is still rare, while it is necessary to know how the use of corporal punishment on children still persists in Indonesia. The common practice of corporal punishment in Indonesia can build adolescents' belief that corporal punishment is harmless and effective as a disciplinary strategy. This study aimed to determine the relationship between age, Big Five personality and the acceptance of corporal punishment myth in adolescents. Participants were 115 adolescents age 13-17 years, domiciled in West Java region and classified as families with middle-lower economic status. Big Five personality was measured using the Indonesian version of the IPIP-BFM-25 (The International Personality Item Pool - Big Five Markers), and the acceptance of corporal punishment myth was measured using CPMS (Corporal Punishment Myth Scale). The correlation test with Rank Spearman found that there was a significant relationship between age, personality dimensions of agreeableness and personality dimensions of conscientiousness with the acceptance of corporal punishment myth. In addition, this study also found that acceptance of corporal punishment myth was significantly associated with the intention of using corporal punishment in the future. These findings can be taken into consideration in making plans to prevent adolescents from using corporal punishment as a discipline strategy in the future.
\end{abstract}

Keywords: corporal punishment; myth; Big Five personality; age; adolescent 


\section{Pendahuluan}

Setiap orang memiliki hak untuk mendapatkan perlindungan dari kekerasan, tidak terkecuali pada anak. Hak asasi dasar dari anak adalah mendapat perlindungan dari kekerasan baik di dalam rumah maupun di luar rumah. Perlindungan dari kekerasan bagi anak telah diatur oleh Negara Indonesia dalam Undang-Undang No. 35 Tahun 2014 pada salah satu ayat yang berbunyi bahwa setiap anak berhak atas kelangsungan hidup, tumbuh dan berkembang serta berhak atas perlindungan dari kekerasan dan diskriminasi. Pada tahun 2017 Pemerintah Indonesia juga sudah berkomitmen untuk melarang semua hukuman fisik pada anak, termasuk di rumah (Global Initiative to End All Corporal Punishment of Children, 2018). Meskipun aturan mengenai perlindungan anak dari kekerasan fisik sudah ditetapkan, namun masih ditemukan beberapa anak yang mendapatkan hukuman fisik dari orangtua (Windari, dkk. 2018). Hasil survey yang dilakukan oleh Kim (2019) pada 1.231 orangtua di Indonesia menunjukkan bahwa sebagian besar orangtua (sebanyak 73\%) masih menerapkan hukuman fisik di rumah.

Hukuman fisik adalah penggunaan kekuatan fisik dengan tujuan menyebabkan anak mengalami rasa sakit atau ketidaknyamanan pada tubuhnya, untuk tujuan memperbaiki atau menghukum perilaku anak (Gershoff, 2008). Beberapa bentuk perilaku hukuman fisik yang dilakukan oleh orang tua seperti memukul, menampar area badan (tangan, lengan, kaki), menampar area wajah (muka, mulut, kepala, telinga), mendorong, mencubit, memukul dengan benda (sabuk, tongkat), mencuci mulut dengan sabun, atau mengoleskan sambal ke lidah anak (Fréchette \& Romano, 2017).

Mengacu pada data dari Sistem Informasi Online Perlindungan Perempuan dan Anak dari Kementerian Pemberdayaan Perempuan dan Perlindungan Anak (Kemen PPPA,
2020), diketahui kasus kekerasan pada anak di tahun 2020 telah mencapai 8.436 kasus dan terus bertambah setiap harinya, dimana kekerasan terbanyak dialami oleh anak usia 13-17 tahun sebanyak 4.830 kasus. Data ini menunjukkan bahwa tingkat kekerasan pada anak di Indonesia masih cukup tinggi. Pada negara-negara berkembang, penggunaan hukuman fisik merupakan suatu hal yang umum. Penelitian yang dilakukan oleh Lansford \& Deater-Deckard (2012) pada 24 negara berkembang dengan melibatkan 30.470 keluarga yang memiliki anak usia 2-4 tahun, menunjukkan bahwa sebanyak $29 \%$ orangtua menyatakan kepercayaan mereka bahwa penggunaan hukuman fisik diperlukan untuk membesarkan anak dengan benar, dan hampir dua pertiga orang tua menyatakan bahwa bulan sebelumnya mereka telah memberikan hukuman fisik pada anak.

Hasil penelitian sebelumnya telah menemukan bahwa hukuman fisik dapat memberikan dampak negatif terhadap perkembangan anak (Gershoff \& GroganKaylor, 2016; Grogan-Kaylor dkk., 2018). Meta-analisis yang dilakukan oleh Gershoff \&Grogan-Kaylor (2016) menunjukkan bahwa anak yang mengalami hukuman fisik pada masa kecil lebih banyak menunjukkan perilaku agresi, perilaku antisosial, masalah eksternalisasi (Ward dkk., 2019), masalah internalisasi, masalah kesehatan mental (Pace dkk., 2019), dan lebih banyak yang memiliki hubungan negatif dengan orang tua. Kekerasan pada anak juga secara signifikan dikaitkan dengan rendahnya internalisasi moral, penurunan kemampuan kognitif (Font \& Cage, 2018; Wolf \& Suntheimer, 2020), dan penghargaan diri pada anak di masa yang akan datang (Gershoff \& Grogan-Kaylor, 2016).

Meskipun banyak penelitian telah menunjukkan bahwa hukuman fisik dapat memberikan dampak negatif pada anak, namun beberapa orangtua masih menggu- 
nakan hukuman fisik sebagai strategi disiplin bagi anak. Kish \& Newcombe (2015) menyebutkan bahwa adanya ketidaksesuaian antara bukti dan penggunaan hukuman fisik dipengaruhi oleh kepercayaan atau mitos umum tentang penggunaan hukuman fisik, khususnya mitos yang terkait dengan keefektifan dan tidak membahayakannya hukuman fisik. "Mitos" dikatakan memiliki fungsi psikologis, yaitu membantu individu untuk memahami dunia di sekitar mereka. Sistem kepercayaan ini dikatakan berfungsi sebagai cara untuk membuat dunia menjadi tempat yang stabil, tertib, dan dapat diprediksi (Furnham, 2005).

Hukuman fisik yang diberikan orangtua dapat mempengaruhi bagaimana pandangan remaja terkait dengan pola pengasuhan (Kitano dkk., 2018). Kuhl dkk. (2012) menjelaskan bahwa masa remaja merupakan masa berkembangnya sumber daya kognitif dan psikologis yang dapat mengarahkan pada pengambilan keputusan. Masa remaja juga merupakan masa dimana aset manusia dan sosial yang diperoleh akan membentuk kehidupan mereka di kemudian hari (Kuhl dkk., 2012). Perkembangan sikap mengenai kesesuaian dan efektivitas hukuman fisik merupakan komponen penting dari kognisi sosial yang mendasari transmisi antargenerasi mengenai strategi disiplin menggunakan hukuman fisik (Deater-deckard dkk., 2003). Hal ini didukung dengan beberapa penelitian sebelumnya (Kish \& Newcombe, 2015; Watakakosol dkk., 2019) yang menemukan bahwa anak yang memiliki penerimaan lebih baik terhadap mitos hukuman fisik, memiliki intensi yang lebih tinggi untuk menggunakan hukuman fisik di masa mendatang.

Penerimaan dan kepercayaan seseorang terhadap suatu mitos juga dapat dipengaruhi oleh kepribadian yang dimilikinya. Penelitian yang dilakukan oleh Langston \& Sykes (1997) menunjukkan bahwa kepercayaan atau keyakinan seseorang terhadap sesuatu berkorelasi dengan perbedaan kepribadian yang dimilikinya. Salah satu model kepribadian yang cukup dikenal dan banyak digunakan dalam disiplin ilmu psikologi adalah model kepribadian Big Five. McCrae \& Costa (1996) menjelaskan bahwa trait kepribadian Big Five merupakan karakteristik dari kecenderungan dasar. Sedangkan kepercayaan digambarkan sebagai adaptasi dari karakteristik; kepercayaan dianggap sejalan dengan kecenderungan dasar seseorang (McCrae \& Costa, 1996). Smidt dkk. (2015) menjelaskan bahwa kerangka berpikir ini dapat menjadi landasan bahwa kepribadian Big Five mungkin sangat sensitif dalam mempengaruhi kepercayaan. Hal ini dibuktikan dengan beberapa hasil penelitian (Smidt dkk., 2015; Watakakosol dkk., 2019) bahwa kepribadian menjadi salah satu faktor yang berhubungan dengan penerimaan seseorang terhadap suatu kepercayaan atau mitos. Secara spesifik, penelitian yang dilakukan oleh (Watakakosol dkk., 2019) menemukan bahwa individu yang memiliki kepribadian dengan domain agresi dan permusuhan yang tinggi cenderung lebih mendukung penggunaan hukuman fisik pada anak. Berdasarkan hal ini peneliti mempertimbangkan bahwa karakteristik kepribadian, lebih spesifik kepribadian Big Five, mungkin dapat berhubungan dengan kepercayaan terhadap mitos hukuman fisik.

Faktor lain yang mungkin mendukung adanya kepercayaan yang lebih tinggi terhadap mitos mengenai hukuman fisik ialah usia. Usia menjadi salah satu faktor penting yang dapat menentukan evaluasi anak terhadap hal-hal yang ia alami. Vittrup \& Holden (2010) menemukan bahwa anak yang usianya lebih muda cenderung menilai pukulan sebagai sesuatu yang lebih wajar dibandingkan dengan anak yang usianya lebih tua. Sedangkan penelitian kualitatif yang dilakukan oleh (Gwirayi, 2011) pada remaja di Afrika menunjukkan bahwa remaja memandang hukuman fisik sebagai suatu 
hal yang wajar dan hukuman fisik diperlukan sebagai upaya untuk mendisiplinkan perilaku. Berdasarkan hal ini, perlu juga dipertimbangkan kemungkinan bahwa anak yang usianya lebih tua akan memandang hukuman fisik sebagai sesuatu hal yang wajar dikarenakan penggunaan hukuman fisik masih dianggap normatif dan nilai-nilai yang telah ia terima di lingkungan ini dapat mempengaruhi kepercayaan remaja mengenai mitos hukuman fisik. Hal ini tentunya penting untuk diteliti, dengan asumsi bahwa usia dapat menjadi salah satu prediktor penting yang membentuk kepercayaan terhadap mitos hukuman fisik.

Sampai saat ini penelitian mengenai mitos terhadap hukuman fisik di Indonesia masih jarang dilakukan, padahal hal ini perlu menjadi perhatian untuk mengetahui bagaimana penggunaan hukuman fisik masih bertahan di Indonesia. Oleh karena itu, penelitian ini bertujuan untuk mengetahui hubungan antara faktor usia, kepribadian big five dengan penerimaan mitos hukuman fisik pada remaja, serta mengetahui bagaimana hubungan antara penerimaan mitos hukuman fisik terhadap intensi penggunaan hukuman fisik di masa depan. Selain itu, penelitian ini berfokus pada remaja dengan keluarga yang termasuk dalam sosio-ekonomi menengah ke bawah, karena penelitian menunjukkan bahwa kondisi ini memungkinkan anak lebih rentan mengalami hukuman fisik (Choi dkk., 2018; Vittrup \& Holden, 2010). Penelitian ini diharapkan dapat menjadi pertimbangan ketika merencanakan strategi dalam upaya mencegah menggunakan hukuman fisik pada remaja di masa depan.

\section{Metode}

\section{Partisipan}

Partisipan penelitian berjumlah 115 orang yang terdiri dari 30 laki-laki $(26,1 \%)$ dan 85 perempuan $(73,9 \%)$. Detail untuk data sosio- demografidapatdilihat pada Tabel 1. Partisipan penelitian dipilih menggunakan teknik sampel non-probability sampling dengan bentuk purposive sampling. Karakteristik partisipan dalam penelitian ini yaitu, remaja dengan rentang usia 13-17 tahun, domisili di wilayah Jawa Barat, termasuk dalam keluarga dengan status ekonomi menengah kebawah dan telah bersedia serta mendapatkan izin dari orangtua untuk berpartisipasi dalam penelitian ini dengan mengisi formulir kesediaan (informed consent). Pengambilan data seluruhnya dilakukan secara online dengan mengisi Google Form dikarenakan pandemi COVID-19 dan adanya himbauan untuk melakukan physical distancing.

Peneliti melakukan screening untuk mengetahui status ekonomi partisipan dengan menggunakan pendekatan asesmen yang dibuat oleh Nielsen (2017). Nielsen (2017) mengklasifikasikan status sosial ekonomi masyarakat Indonesia menjadi lima kelompok, yaitu Kelompok A (kelas atas), Kelompok B (kelas menengah atas), Kelompok $\mathrm{C}$ (kelas menengah), Kelompok $D$ (kelas menengah bawah), dan Kelompok E (kelas bawah). Klasifikasi status sosial ekonomi masyarakat ini didasari oleh sumber air minum, kapasitas daya listrik, jenis bahan bakar yang digunakan untuk memasak, dan jumlah pengeluaran rata-rata untuk keperluan rumah tangga per bulan (Nielsen, 2017). Remaja yang termasuk dalam kelompok $D$ (menengah bawah) dengan kelompok $\mathrm{E}$ (kelas bawah) dipilih menjadi partisipan pada penelitian ini. 
Tabel 1. Gambaran Karakteristik Sosio-Demografis Partisipan

\begin{tabular}{llcr}
\hline & Karakteristik & Jumlah (n) & Persentase (\%) \\
\hline \multirow{3}{*}{ Jenis Kelamin } & Laki-Laki & 30 & 26,1 \\
& Perempuan & 85 & 73,9 \\
& 13 & 11 & 9,6 \\
& 14 & 15 & 13 \\
\multirow{4}{*}{ Pendidikan } & 15 & 18 & 15,7 \\
& 16 & 28 & 24,3 \\
& 17 & 43 & 37,4 \\
Domisili & SD & 1 & 0,9 \\
& SMP & 25 & 21,7 \\
& SMA/SMK & 89 & 77,4 \\
& Bandung & 18 & 15,7 \\
& Bekasi & 10 & 8,7 \\
& Bogor & 4 & 3,5 \\
& Cianjur & 13 & 11,3 \\
& Cimahi & 10 & 8,7 \\
& Depok & 1 & 0,9 \\
& Garut & 12 & 10,4 \\
& Karawang & 1 & 0,9 \\
& Subang & 2 & 1,7 \\
& Sukabumi & 1 & 0,9 \\
& Sumedang & 26 & 22,6 \\
& Tasikmalaya & 17 & 14,8 \\
& & & \\
& & &
\end{tabular}

\section{Pengukuran}

Kepercayaan atau penerimaan individu terhadap mitos mengenai hukuman fisik diukur menggunakan Corporal Punishment Myth Scale (CPMS: Kish \& Newcombe, 2015). CPMS terdiri dari 10 item yang sudah diadaptasi ke Bahasa Indonesia. Uji coba alat ukur yang telah dilakukan menunjukkan bahwa CPMS memiliki validitas dan reliabilitas yang baik $(\alpha=0.916)$. CPMS terdiri dari dua faktor laten yaitu "hukuman fisik sebagai sesuatu yang tidak berbahaya" (terdiri dari lima item, contoh: "penggunaan hukuman fisik mengajarkan rasa tanggung jawab dan membantu mengembangkan karakter anak") dan "penggunaan hukuman fisik dianggap penting dan efektif" (terdiri dari 5 item, contoh: "hukuman fisik bekerja lebih baik daripada metode disiplin lainnya"). CPMS menggunakan skala Likertyang terdiri dari lima pilihan jawaban bergerak dari 1 (sangat tidak setuju) sampai dengan 5 (sangat setuju). Total skor yang diperoleh dengan menjumlahkan keseluruhan jawaban, semakin tinggi skor CPMS maka semakin tinggi kepercayaan terhadap mitos penggunaan hukuman fisik.

IPIP-BFM-25 (The International Personality Item Pool - Big Five Markers) versi Bahasa Indonesia (Akhtar \& Azwar, 2018) digunakan untuk mengukur trait kepribadian Big Five. IPIP-BFM-25 versi Bahasa Indonesia, dikembangkan dari alat ukur IPIP-BFM-50 yang disusun oleh (Goldberg, 1992). IPIP-BFM-25 terdiri dari 25 item dan lima dimensi (Extraversion, Agreeableness, Conscientiousness, Emotional stability, dan Intellect) dengan masing-masing lima item. IPIP-BFM-25 menggunakan skala Likert dengan lima pilihan jawaban yang bergerak dari sangat tidak sesuai sampai dengan sangat sesuai. Item-item akan diberikan skor dan dijumlahkan untuk memperoleh skor total pada masing-masing dimensi. IPIP-BFM-25 diketahui memiliki validitas dan reliabilitas yang baik (seluruh dimensi memiliki koefisien reliabilitas diatas 0.7) (Akhtar \& Azwar, 2018). 
Intensi penggunaan hukuman fisik di masa depan diukur melalui skenario yang dikembangkan oleh Kish \& Newcombe (2015) dan telah diadaptasi kedalam Bahasa Indonesia. Skenario ini menggambarkan perselisihan yang terjadi antara ibu dan anak. Skenario penggunaan hukuman fisik dibedakan berdasarkan; tipe perilaku buruk anak (mengamuk atau memukul ibu), dimana perilaku tersebut ditunjukkan (tempat umum atau rumah), jenis kelamin anak (laki-laki atau perempuan) dan usia anak (4 tahun atau 9 tahun). Jadi akan ada empat bentuk skenario yaitu; mengenai anak laki-laki usia 4 tahun, anak laki-laki usia 9 tahun, anak perempuan usia 4 tahun, anak perempuan usia 9 tahun. Lalu partisipan akan memilih salah satu skenario tersebut secara acak.

Partisipan diminta untuk memposisikan dirinya sebagai orangtua dan bagaimana respon mereka terhadap setiap skenario dalam kaitannya mendisiplinkan anak, apakah mereka akan menggunakan hukuman fisik (misalnya, memukul, menampar, mencubit menyambuk), mengabaikan perilaku buruk anak, memberikan anak "time out", menjelaskan pada anak bahwa apa yang mereka lakukan itu salah, atau menggunakan teknik disiplin lain. Contoh skenario yang digunakan pada penelitian ini ditunjukkan dalam Tabel 2. Respon partisipan untuk setiap skenario akan diberikan skor, jika tidak menggunakan hukuman fisik maka skornya nol (0) dan jika menggunakan hukuman fisik akan diberikan skor satu (1). Total skor yang dapat diperoleh partisipan yaitu dari 0 sampai 4. Semakin tinggi skor yang diperoleh maka semakin tinggi intensi penggunaan hukuman fisik.

\section{Tabel 2. Contoh Skenario Intensi Penggunaan Hukuman Fisik}

\begin{tabular}{|c|c|c|}
\hline Lokasi & $\begin{array}{l}\text { Perilaku } \\
\text { Buruk }\end{array}$ & $\begin{array}{c}\text { Contoh Skenario } \\
\text { (Antara anak berusia 4/9 tahun; } \\
\text { Laki-laki (Aldi) atau Perempuan (Luna) }\end{array}$ \\
\hline Rumah & Memukul & $\begin{array}{l}\text { Pada suatu sore, Aldi/Luna sedang menonton acara TV favoritnya, } \\
\text { disaat ibunya memasak untuk makan malam. Selama menonton } \\
\text { dengan serius dan fokus, ibu memintanya untuk mematikan TV } \\
\text { karena sudah masuk waktu makan malam. Namun, Aldi tetap } \\
\text { tertarik untuk menonton program TV favoritnya, dan berteriak, } \\
\text { "TIDAK!" lalu memukul ibunya. Sebagai orangtua, bagaimana } \\
\text { responmu terhadap perilaku Aldi? }\end{array}$ \\
\hline
\end{tabular}

Tempat Mengamuk Pada suatu sore, Aldi/ Luna sedang makan malam di restoran Umum dengan kedua orangtuanya. Saat tengah menikmati makanannya, ibu memintanya secara baik-baik untuk menghabiskan seluruh makanan yang ada di piringnya, termasuk dengan sayurannya. Namun, Aldi menolak menuruti ibu dan mulai melemparkan makanan-makanannya ke lantai, sambil marah dan memaksa ibu mengerti kalau ia tidak menyukai dan tidak mau memakan tomat dan wortel. Sebagai orangtua, bagaimana responmu terhadap perilaku Aldi?

\section{Analsis Data}

Penelitian ini menggunakan pendekatan kuantitatif non-eksperimental dengan metode korelasional. Uji korelasi dilakukan untuk mengetahui hubungan antara usia, kepribadian Big Five dengan penerimaan mitos penggunaan hukuman fisik. Penelitian ini juga menguji hubungan antara mitos hukuman fisik dan intensi penggunaan hukuman fisik di masa depan. Analisis statistik dilakukan menggunakan software IBM SPSS Statistics 22. Penelitian ini menggunakan teknik analisis statistik deskriptif untuk memperoleh gambaran karakteristik partisipan meliputi jenis kelamin, usia, pendidikan dan domisili. Uji normalitas Shapiro Wilk digunakan untuk 
mengetahui apakah data mengenai mitos hukuman fisik dan kepribadian Big Five berdistribusi normal, hasilnya diketahui bahwa data mitos hukuman fisik berdistribusi normal sedangkan data kepribadian Big Five tidak berdistribusi normal. Selanjutnya, Uji korelasi Rank Spearman dilakukan untuk mengetahui hubungan antara usia, kepribadian Big Five dan mitos hukuman fisik. Penelitian ini juga melakukan uji korelasi untuk mengetahui hubungan antara penerimaan mitos hukuman fisik dengan intensi penggunaan hukuman fisik di masa depan. Hasil uji korelasi yang diperoleh akan diinterpretasi berdasarkan kriteria dari Cohen dengan melihat nilai koefisien korelasi Spearman rho, $0.1=$ kecil; 0.3 = sedang dan $0.5=$ besar (Cohen, 1988).

\section{Hasil}

Berdasarkan hasil data deskriptif (Tabel 3), secara umum penerimaan remaja terhadap mitos hukum fisik cukup bervariasi ( $M=28,32$; $S D=9,14)$. Namun, sebagian besar remaja melihat bahwa hukuman fisik sebagai sebagai strategi disiplin yang tidak berbahaya dan dianggap penting serta efektif bagi anak ( $\mathrm{M}=$ $13,57 ; S D=5,13 ; M=14,76 ; S D=4,95)$.

Tabel 3. Data Deskriptif Setiap Variabel

\begin{tabular}{crrrr}
\hline Variabel & $\begin{array}{c}\text { Skor } \\
\text { Minimum }\end{array}$ & $\begin{array}{c}\text { Skor } \\
\text { Maksimum }\end{array}$ & Rata-Rata & $\begin{array}{c}\text { Simpangan } \\
\text { Baku }\end{array}$ \\
\hline Mitos Hukuman Fisik & 10 & 50 & 28,32 & 9,14 \\
Tidak Berbahaya & 5 & 13,57 & 5,13 & 25 \\
Penting dan Efektif & 5 & 14,76 & 4,95 & 25 \\
Kepribadian Big Five & & & & \\
Extraversion & 5 & 16,67 & 3,997 & 25 \\
Agreeableness & 13 & 21,09 & 3,27 & 25 \\
Conscientiousness & 8 & 17,73 & 4 & 25 \\
Emotional Stability & 5 & 11,32 & 3,99 & 22 \\
Intellect & 12 & 17,22 & 2,56 & 23 \\
\hline
\end{tabular}

Hasil uji korelasi antara usia, kepribadian dan penerimaan mitos hukuman fisik ditunjukkan pada Tabel 4. Usia secara signifikan berhubungan dengan penerimaan mitos hukuman fisik pada remaja $(r=-0,451)$, artinya semakin muda usia seorang remaja, semakin tinggi penerimaan mitos hukuman fisik yang dimilikinya. Usia dan penerimaan mitos hukuman fisik memiliki hubungan yang tergolong sedang menuju besar.

Tabel 4. Korelasi Antar Variabel Penelitian
Pada variabel kepribadian Big Five, dimensi kepribadian yang berhubungan secara signifikan dengan penerimaan mitos hukuman fisik adalah agreeableness $(r=0,213)$ dan conscientiousness $(r=0,247)$. Hal ini menunjukkan bahwa semakin tinggi kepribadian agreeableness dan conscientiousness, semakin tinggi penerimaan mitos hukuman fisik. Kedua dimensi kepribadian ini memiliki hubungan dengan derajat kekuatan kecil menuju sedang.

\begin{tabular}{lccc}
\multicolumn{1}{c}{ Variabel Independen } & \multicolumn{2}{c}{ Mitos Hukuman Fisik } \\
\cline { 3 - 4 } Usia & \multicolumn{1}{c}{$\boldsymbol{r}$} & $\boldsymbol{p}$ \\
Kepribadian Big Five & Extraversion & $-0,451$ & $-0,451^{* *}$ \\
& Agreeableness & 0,163 & 0,163 \\
Conscientiousness & 0,213 & $0,213^{*}$ \\
& Emotional stability & 0,247 & $0,247^{* *}$ \\
& Intellect & $-0,002$ & $-0,002$ \\
Intensi Penggunaan Hukuman Fisik & 0,016 & 0,016 \\
\multicolumn{2}{c}{${ }^{* *}$ signifikansi pada level $p<0,001 ;{ }^{*}$ signifikansi pada level $p<0,05$} & $0,214^{*}$ \\
\hline
\end{tabular}


Penelitian ini juga menemukan bahwa penerimaan mitos hukuman fisik pada remaja secara signifikan berhubungan dengan intensi penggunaan hukuman fisik di masa depan $(r=$ 0,214). Artinya, semakin tinggi penerimaan mitos hukuman fisik, semakin tinggi intensi seorang remaja dalam menggunakan hukuman fisik di masa depan. Mitos hukuman fisik dan intensi penggunaan hukuman fisik memiliki derajat hubungan sedang menuju besar.

\section{Pembahasan}

Hasil menunjukkan bahwa sebagian besar remaja menganggap bahwa penerapan hukuman fisik tidak membahayakan dan dianggap penting serta efektif. Berdasarkan tinjauan literatur yang dilakukan oleh Chiocca (2017), salah satu faktor yang dapat mempengaruhi dukungan terhadap hukuman fisik adalah keyakinan bahwa hukuman fisik merupakan sesuatu yang normatif. Hal ini didukung oleh hasil survey yang dilakukan oleh Kim (2019) pada 1.231 orangtua di Indonesia menunjukkan bahwa sebanyak $32 \%$ orangtua berpendapat bahwa hukuman fisik harus dibuat legal dan sebagian besar orangtua (sebanyak 73\%) masih menerapkan hukuman fisik di rumah. Hasil ini menunjukkan bahwa penerapan hukuman fisik di Indonesia masih dianggap normatif dan hal ini mungkin menjadi faktor yang mempengaruhi penerimaan mitos hukuman fisik pada remaja.

Berdasarkan uji korelasi, ditemukan bahwa adanya hubungan negatif antara usia dan penerimaan mitos hukuman fisik. Hasil temuan ini sejalan dengan penelitian sebelumnya bahwa anak yang memiliki usia lebih muda cenderung menilai hukuman fisik (mis. pukulan) sebagai sesuatu yang lebih wajar dibandingkan dengan anak yang usianya lebih tua (Vittrup \& Holden, 2010). Usia menjadi salah satu faktor penting yang menentukan evaluasi yang dilakukan oleh anak. Penelitian yang dilakukan oleh Catron \& Masters (1993) menemukan bahwa anak usia prasekolah menilai pukulan sebagai bentuk disiplin yang dapat diterima untuk jenis pelanggaran apapun, sedangkan pada usia siswa kelas 5 SD hanya bersedia diberikan hukuman berupa pukulan jika melakukan pelanggaran yang berkaitan dengan perilaku yang membahayakan atau melanggar hukum tertentu. Semakin bertambah usia, maka kemampuan kognitif anak-anak juga semakin berkembang, keterampilan penalaran meningkat, dan rasa otonomi tubuh (Catron \& Masters, 1993). Anak yang usianya lebih besar cenderung menilai bahwa pukulan dan hukuman fisik lain bukan sebagai bentuk disiplin yang sah dan adil (Vittrup \& Holden, 2010).

Selanjutnya, penelitian ini menemukan adanya korelasi positif antara mitos hukuman fisik dengan dimensi kepribadian agreeableness dan conscientiousness. Dweck (2008) menjelaskan bahwa keper-cayaan mencakup representasi mental mengenai cara kerja diri, hubungan dengan orang lain serta dunia. Lebih lanjut Dweck (2008) menyebutkan bahwa banyak ahli teori kepribadian dari berbagai pendekatan mengakui bahwa kepercayaan merupakan bagian fundamental dari kepribadian. Hal ini sejalan dengan beberapa penelitian sebelumnya yang menemukan hubungan antara kepribadian dengan kepercayaan seseorang (Langston \& Sykes, 1997; Smidt dkk., 2015; Watakakosol dkk., 2019). Dimensi kepribadian conscientiousness menggambarkan kepribadian yang terorganisir, tekun dan adanya kecenderungan terhadap keteraturan dan ketaatan (Strus dkk., 2014). Karakteristik keteraturan dan ketaatan yang tergambarkan dalam dimensi kepribadian conscientiousness dapat menjadi faktor yang menyebabkan adanya hubungan positif antara kepribadian conscientiousness dengan mitos hukuman fisik pada remaja. Akan tetapi hubungan positif antara dimensi kepribadian agreeableness dengan penerimaan mitos hukuman fisik merupakan hasil penelitian yang tidak terduga. Pada pendekatan leksikal kepribadian Big Five, dimensi agreeableness 
menggambarkan karakteristik individu yang hangat dan memiliki sikap positif pada orang lain (Strus dkk., 2014). Namun, Strus dkk. (2014) menjelaskan bahwa jika dilihat berdasarkan pendekatan tradisional, dimensi kepribadian agreeableness merefleksikan kecenderungan kesopanan dan moralitas.

Disamping itu, hasil penelitian yang dilakukan oleh Bell \& Romano (2012) menunjukkan bahwa anak yang banyak mengalami hukuman fisik namun juga mendapatkan kehangatan atau dukungan dari orangtua memiliki sikap yang lebih baik terhadap pukulan sebagai hukuman fisik. Hal ini dapat dijadikan pertimbangan bahwa seseorang yang memiliki kepribadian yang hangat atau kecenderungan agreeableness yang lebih tinggi juga dapat memiliki penerimaan yang lebih baik terhadap mitos hukuman fisik karena pengalaman hukuman fisik yang diterimanya dan lingkungan keluarga yang tetap hangat atau suportif. Oleh karena itu, dibutuhkan analisis lebih lanjut lagi terkait hubungan antara dimensi kepribadian agreeableness dengan mitos hukuman fisik.

Hubungan positif antara penerimaan mitos hukuman fisik dengan intensi penggunaan hukuman fisik di masa depan juga sejalan dengan beberapa hasil penelitian sebelumnya (Kish \& Newcombe, 2015; Watakakosol dkk., 2019). Sikap positif terhadap hukuman fisik dapat berpengaruh terhadap penurunan pada generasi selanjutnya dalam menggunakan metode hukuman fisik sebagai strategi disiplin. Hal ini sesuai dengan penelitian dari Simons \& Wurtele (2010) bahwa secara signifikan penerimaan orangtua terhadap penggunaan hukuman fisik berhubungan positif dengan frekuensi penggunaan hukuman fisik pada anak mereka. Penelitian longitudinal dapat dilakukan untuk membuktikan bahwa mitos hukuman fisik yang dimiliki pada masa remaja dapat mempengaruhi strategi disiplin yang digunakan di masa depan.

Penelitian ini memiliki beberapa limitasi yang perlu diperhatikan dan dapat dija- dikan pertimbangan untuk melakukan penelitian selanjutnya. Pertama, kurangnya jumlah sampel karena keterbatasan dalam menjangkau partisipan yang termasuk dalam keluarga dengan status ekonomi menengah ke bawah. Untuk penelitian selanjutnya mungkin dapat mempertimbangkan strategi dalam mengakses partisipan, sehingga dapat menjaring lebih banyak partisipan supaya hasil penelitian dapat lebih tergeneralisasi. Kedua, hasil penelitian ini hanya menggali korelasi dan tidak menguji bagaimana kausalitas antar variabel. Selain itu, penelitian ini tidak menggali bagaimana pengalaman remaja terkait hukuman fisik. Hal ini dapat dijadikan pertimbangan bagi peneliti selanjutnya untuk menguji hubungan antara pengalaman hukuman fisik dan penerimaan mitos hukuman fisik pada remaja. Penelitian selanjutnya juga dapat menggunakan metode analisis lain serta mengeksplorasi variabel-variabel lain yang mungkin berkaitan dengan penerimaan mitos hukuman fisik, sehingga dapat diperoleh pemahaman lebih menyeluruh.

\section{Kesimpulan}

Hasil penelitian ini menunjukkan bahwa usia, kepribadian agreeableness dan kepribadian conscientiousness secara signifikan berhubungan positif dengan penerimaan mitos hukuman fisik pada remaja. Penerimaan mitos hukuman fisikjuga diketahui memiliki hubungan yang positif dengan intensi penggunaan hukuman fisik di masa depan, artinya semakin tinggi penerimaan mitos hukuman fisik maka semakin tinggi intensi dalam menggunakan hukuman fisik di masa depan. Hasil dari penelitian ini dapat menjadi pertimbangan untuk membuat rancangan strategi dalam mencegah remaja menggunakan hukuman fisik ketika mereka menjadi orangtua di masa depan. Saran bagi penelitian selanjutnya untuk mengeksplorasi faktor-faktor lain yang mungkin berhubungan atau menjadi prediktor dalam penerimaan mitos hukuman fisik pada remaja. 


\section{Daftar Pustaka}

Akhtar, H., \& Azwar, S. (2018). Development and Validation of a Short Scale for Measuring Big Five Personality Traits: the IPIP-BFM-25 Indonesia. Journal of Innovation in Psychology, Education and Didactics, 22(2), 167-174. http://ipip.ori. org/index.htm

Bell, T., \& Romano, E. (2012). Opinions About Child Corporal Punishment and Influencing Factors. https://doi. org/10.1177/0886260511432154

Catron, T. F., \& Masters, J. C. (1993). Mothers ' and Ghildren's Conceptualizations of Corporal Punishment. 1815-1828.

Chiocca, E. M. (2017). American Parents ' Attitudes and Beliefs About Corporal Punishment: An Integrative Literature Review. Journal of Pediatric Health Care, 2002, 1-12. https://doi.org/10.1016/j. pedhc.2017.01.002

Choi, S., Yoo, J., Park, J., Lee, H. Y., Tran, H. T. G., Lee, J. K., \& Oh, J. (2018). Manifestations of socioeconomic status and its association with physical child punishment- Results from the Multi-Indicators Cluster Survey in Viet Nam, 2006-2014. Child Abuse and Neglect, 85(August), 1-8. https://doi. org/10.1016/j.chiabu.2018.08.022

Cohen, J. (1988). Statistical power analysis for the behavioral science (2nd ed.). Erlbaum Associates.

Deater-deckard, K., Lansford, J. E., Dodge, K. A., Pettit, G. S., \& Bates, J. E. (2003). The Development of Attitudes About Physical Punishment: An 8-Year Longitudinal Study. 17(3), 351-360. https://doi. org/10.1037/0893-3200.17.3.351

Dweck, C. S. (2008). Can Personality Be Changed? The Role of Beliefs in Personality and Change. 17(6), 391394.

Font, S. A., \& Cage, J. (2018). Child Abuse \& Neglect Dimensions of physical punishment and their associations with children's cognitive performance and school adjustment. Child Abuse \& Neglect, 75(July 2017), 29-40. https:// doi.org/10.1016/j.chiabu.2017.06.008

Furnham, A. (2005). Spare the rod and spoil the child: Lay theories of corporal punishment. In Corporal punishment of children in theoretical perspective (pp. 134-151). Yale University Press.

Gershoff, E. T. (2008). Report on physical punishment in the United States: What research tells us about its effect on children. Center for Effective Discipline.

Gershoff, Elizabeth T, \& Grogan-Kaylor, A. (2016). Spanking and Child Outcomes: Old Controversies and New MetaAnalyses. 30(4), 453-469.

Global Initiative to EndAll Corporal Punishment of Children. (2018). Corporal punishment of children in Indonesia (Issue January).

Goldberg, L. R. (1992). The Development of Markers for the Big-Five Factor Structure. Psychological Assessment, 4(1), 26-42.

Grogan-kaylor, A., Burlaka, V., Ma, J., Lee, S., \& Castillo, B. (2018). Children and Youth Services Review Predictors of parental use of corporal punishment in Ukraine i2. Children and Youth Services Review, 88(November 2017), 66-73. https://doi. org/10.1016/j.childyouth.2018.03.003

Gwirayi, P. (2011). Functions Served by Corporal Punishment : Adolescent Perspectives Functions Served by Corporal Punishment: Adolescent Perspectives. 21(1), 121-124. https://doi.org/10.1080/ 14330237.2011.10820437

Kish, A. M., \& Newcombe, P. A. (2015). "Smacking never hurt me!" Identifying myths surrounding the use of corporal punishment. Personality and Individual Differences, 87, 121-129. https://doi. org/10.1016/j.paid.2015.07.035

Kitano, N., Yoshimasu, K., Yamamoto, B. A., \& Nakamura, Y. (2018). Associations between childhood experiences of parental corporal punishment and neglectful parenting and undergraduate students' endorsement of corporal punishment as an acceptable parenting 
strategy. PLoSONE, 13(10),1-16. https:// doi.org/10.1371/journal.pone.0206243

Kuhl, D. C., Warner, D. F., \& Wilczak, A. (2012). Adolescent violent victimization and precocious union formation. Criminology, 50(4), 1089-1127. https://doi. org/10.1111/j.1745-9125.2012.00288.x

Langston, C. A., \& Sykes, W. E. (1997). Beliefs and the Big Five: Cognitive Bases of Broad Individual Differences in Personality. Journal of Research in Personality, 31(2), 141-165. https://doi. org/10.1006/jrpe.1997.2178

Lansford, J. E., \& Deater-Deckard, K. (2012). Childrearing discipline and violence in developing countries. Child Development, 83(1), 62-75. https://doi. org/10.1111/j.1467-8624.2011.01676.x

Pace, G. T., Lee, S. J., \& Grogan-Kaylor, A. (2019). Spanking and young children's socioemotional development in lowand middle-income countries. Child Abuse and Neglect, 88(June 2018), 84-95. https://doi.org/10.1016/j. chiabu.2018.11.003

Simons, D. A., \& Wurtele, S. K. (2010). Relationships between parents' use of corporal punishment and their children's endorsement of spanking and hitting other children. Child Abuse and Neglect, 34(9), 639-646. https://doi.org/10.1016/j. chiabu.2010.01.012

Smidt, W., Kammermeyer, G., \& Roux, S. (2015). Relations between the Big Five personality traits of prospective early childhood pedagogues and their beliefs about the education of preschool children: Evidence from a German study. Learning and Individual Differences, 37, 96-106. https://doi.org/10.1016/j. lindif.2014.11.002

Strus, W., Cieciuch, J., \& Rowiński, T. (2014). The polish adaptation of the IPIPBFM-50 questionnaire for measuring five personality traits in the lexical approach. Roczniki Psychologiczne, 17(2), 327366.

Vittrup, B., \& Holden, G. W. (2010). Children's assessments of corporal punishment and other disciplinary practices: The role of age, race, SES, and exposure to spanking. Journal of Applied Developmental Psychology, 31(3), 211-220. https://doi.org/10.1016/j. appdev.2009.11.003

Ward, K. P., Lee, S. J., Limb, G. E., \& Grogan-Kaylor, A. C. (2019). Physical Punishment and Child Externalizing Behavior: Comparing American Indian, White, and African American Children. Journal of Interpersonal Violence. https:// doi.org/10.1177/0886260519861678

Watakakosol, R., Suttiwan, P., Wongcharee, H., Kish, A., \& Newcombe, P. A. (2019). Parent discipline in Thailand: Corporal punishment use and associations with myths and psychological outcomes. Child Abuse and Neglect, 88(December 2018), 298-306. https://doi.org/10.1016/j. chiabu.2018.12.002

Windari, R., Supanto, \& Novianto, W. T. (2018). Overcoming Corporal Punishment of Children: an Evaluation Toward Indonesian Penal Policy Nowdays. SHS Web of Conferences, 54, 08017. https:// doi.org/10.1051/shsconf/20185408017

Wolf, S., \& Suntheimer, N. M. (2020). Predictors of parental disciplinary practices and associations with child outcomes among Ghanaian preschoolers. Children and Youth Services Review, 112(September 2019), 104518. https://doi.org/10.1016/j. childyouth.2019.104518 